\title{
BIOLOGICAL STUDIES ON THE UROPODID MITE UROOBOVILLA KRANTZI (ZAHER AND AFIFI) (MESOSTIGMATA : UROPODIDAE) WHEN EFD ON TWO DIFFERENT FUNGI
}

\author{
AHMED E. HAGRASS ${ }^{1}$, M. E. E. EL-NAGGAR ${ }^{2}$, E. M. A. YASSIN ${ }^{2}$ AND \\ MARIAM G. SADEK ${ }^{2}$ \\ 1. Zoology Dept., Faculty of Science, Mansoura Univ., Mansoura \\ 2. Plant Protection Research Institute, ARC, Dokki, Giza
}

(Manuscript received 3 October 2010 )

\begin{abstract}
Under laboratory conditions, The current study indicated that the type of tested fungi (food) had slightly significantly difference on the incubation period of uropodid mite, Uroobovilla krantzi (males and females) when fed on the fungi, Fusarium oxysporum and Rhizoctonia solani. Whoever, the obtained data indicated that the type of tested fungi not significantly affected on the life cycle from egg deposition to adult emergence where it recorded 35.1 and 34.6 days when individuals reared on $F$. oxysporum and $R$. solani, for female individuals respectively, changed to 37.3 and 36.5 days for male individuals when fed on the same fungi, respectively. Also the cuurrent study indicated that the type of used fungi had very highly significantly difference effects on the adult male and female longevity. This duration lasted 163.3 and 92.1 days when females fed on $F$. oxysporum and $R$. solani, respectively, but in case of adult males this period averaged 198.4 and 72.1 days on feeding on the same kind of fungi, respectively.The preoviposition, oviposition and postoviposition periods for females lasted 4.8 and 8.3 days, 129.6 and 43.6 days $\& 22.5$ and 28.6 days when the female individuals reared on $F$. oxysporum and $R$. solani, respectively. Significantly more eggs (123.0 eggs) are laid by females when fed on F. oxysporum than when fed on $R$. solani (34.6 eggs).
\end{abstract}

\section{INTRODUCTION}

Mesostigmata or Gamasida are known from a wide range of habitats. Most of them are free living predators in soil and litter, on the soil surface or on plants. Some of them are able to disperse rapidly by phoresy. Also, these mites feed on small invertebrates. In agro- ecosystems, edaphic Mesostigmata are important predators of Collembola and Nematodes, and those living on plants may efficiently control pests like spider mites. Uropodids are free-living mites inhabiting soil. Hughes (1959) suggested that their long poorly developed chelicerae are well adapted for feeding on fungal mycelia and spores or moss. Moreover, Radinovsky and Krantz (1961) and Radinovsky (1965) stated that some uropodids are fungivorous, while Willis and Axtell (1968) recorded some uropodids as predators of house fly larvae Muscae domesticae L. In Egypt, some scattered studies dealt with the biology and feeding habits of 
certain uropodids (Afifi, 1980, El-Bishlawy and Afifi, 1982, Abbassy et al., 1991 and Nawar et al., 1993. Mowafi 2005 reared the uropodid mite, Chiropturopoda bakeri Zaher and Afifi and found that the duration of its developmental stages and reproduction feeding habits were greatly affected by prey species where the free-living nematode Rhabditis scanica Allgen and plant parasitic nematode, Meloidogyne incognita Kofoid \& White were more suitable than housefly larvae for increasing reproductive potentiality of the mite at $25^{\circ} \mathrm{C}$. It was found that the fungivorous mite (Uroobovilla krantzi) is not able to transmit soil fungi Fusarium oxysporum and Rhizoctonia solani nither through their surface nor their faeces, so it was necessary to study it's life-cycle. Zaher (1986) decided that, the uropodid mites, in general, are common in soils rich in organic manure and seem to be feeding on a wide range of diets, including decayed organic materials, fungi. The main aim of this study was to study the development, female and male longevity and fecundity of the uropodid mite, Uroobovilla krantzi Zaher and Afifi when fed on two different fungi Fusarium oxysporum and Rhizoctonia solani in the laboratory at $25^{\circ} \mathrm{C}$ and $80 \%$ R.H.

\section{MATERIALS AND METHODS}

Collection and specimen identification: To rear the fungivorous mite (Uroobovilla krantzi), there are two types of cages were used. The first for culturing mites [large sterilized glass Petri-dishes filled up to $0.5 \mathrm{~cm}$ with a mixture of plaster of Paris and charcoal $(9: 1)$ ], and the second for individual rearing [sterilized plastic rings $2 \mathrm{~cm}$ in diam. and $1.5 \mathrm{~cm}$ in depth filled up to $0.5 \mathrm{~cm}$ with a the same mixture. For culturing mites, several adult females and males of $U$. krantzi were sterilized by immersing them in $2 \%$ sodium hypochlorite solution, then rinsed in sterilized water. The living mites were transferred to the large Petri dishes and supplied with Fusarium oxysporum and Rhizoctonia solani, grown on PDA medium, and kept in an incubator at $25^{\circ} \mathrm{C}$ and $80 \%$ R.H. Drops of sterilized water were added daily to maintain suitable relative humidity.

For individual rearing, Newly deposited eggs were transferred to the sterilized plastic rings. After hatching each larva was supplied with food (Fusarium oxysporum and/or Rhizoctonia solani) in rearing cells consisting of plastic rings $2.8 \mathrm{~cm}$ in diameter and $2.0 \mathrm{~cm}$ deep. All experiments were conducted under a constant temperature (25 $+2{ }^{\circ} \mathrm{C}$ and relative humidity $80+5 \%$ R.H). Observations were made twice daily using stereomicroscope to determine different biological aspects. U. krantzi was maintained at $25^{\circ} \mathrm{C}$ on colonies of (Fusarium oxysporum or Rhizoctonia solani), which had been cultured on potato dextrose agar (PDA) medium (17 - $20 \mathrm{gm}$ agar $+20 \mathrm{gm}$ dextrose sugar $+200 \mathrm{gm}$ crushed potato. A colony of fungus was put in a glass ring $(1.5 \mathrm{~cm}$ in diameter and $1 \mathrm{~cm}$ high) and a single mite was introduced to each colony. High 
vacuum silicon grease was applied and a cover glass was put onto each glass ring to keep the mites from escaping. Petri dishes ( $9 \mathrm{~cm}$ diameter) containing 10 glass rings were placed in incubators, which were set up at various temperatures and a photoperiod of $16 \mathrm{~L}-8 \mathrm{D}$.

\section{RESULTS AND DISCUSSION}

Eggs: The eggs of $U$. krantzi adult females are relatively large and laid in cracks in the substrate.

Mating : Reproduction in U. krantzi is bisexual. The male usually approaches the female from the near and turning over, slips under her and elasps her by the $3^{\text {rd }}$ and $4^{\text {th }}$ pairs of legs. Copulation usually last 4-6 minutes.

Adult: The newly emerged adult of $U$. krantzi males and females are light brown immediately after emergence but it converted to darken to a dark brown within about two days. The adult females are slightly larger and broader than males.

Incubation period: The tabulated data in table (1) showed that the incubation period of uropodid mite, $U$. krantzi not significantly differed when the two sexes (males and females) fed on the two types of introduced fungi, where it recorded 4.0 days on F. oxysporum for both sexes and 4.7 for females and 4.4 days for males on feeding on $R$. solani. Whoever, the statistical analysis of obtained data, table (3) indicated that the type of tested fungi (food) had slightly significantly difference on this incubation period.

Life cycle: Statistical analysis of obtained data, tables (1 and 3) showed that both $F$. oxysporum and $R$. solani significantly affected the developmental duration from egg deposition to adult emergence (life cycle) for both sexes of $U$. krantzi. Thus the female life cycle averaged 35.1 and 34.6 days when individuals reared on $F$. oxysporum and $R$. solani, respectively, changed to 37.3 and 36.5 days for male individuals when fed on the same fungi, respectively.

Longevity: As shown in tables (1,2 and 3), the type of used fungi had very high significantly difference effects on the adult male and female longevity. This duration durated 163.3 and 92.1 days when females fed on F. oxysporum and $R$. solani, respectively, but in case of adult males this period averaged 198.4 and 72.1 days on feeding on the same kind of fungi, respectively.

Preoviposition, oviposition and postoviposition periods: As shown in table (2), longevity of adult female of $U$. krantzi (preoviposition, oviposition and postoviposition periods) was very high significantly differed according to the type of fungi used. Accordingly the different longevity periods were affected. The time taken before eggs laying (Preoviposition) was $4.8 \pm 0.91$ and $8.3 \pm 1.15$ days when the females fed on $F$. 
oxysporum and $R$. solani, respectively. However, the time taken for eggs deposition (oviposition period) was 129.6 days when the females, fed on $F$. oxysporum, decreased significantly till reached to 43.6 days on $R$. solani . However, the feeding on $R$. solani increased the postoviposition period of $U$. krantzi (28.6 days) in comparison with the time recorded on F. oxysporum 22.5 days.

Fecundity: Mating is essential for egg deposition. Eggs production in U. krantzi is influenced by the type of food ingested, table (2). Fecundity was significantly higher when the adult female fed on $F$. oxysporum where it deposited 123.0 eggs in her oviposition period in comparison with 34.6 eggs when the individuals fed on $R$. solani. Within Uropodina, the reproduction rate of females varies greatly according to species and diet. The feeding habits of most species of the family Uropodidae are unknown, but the family apparently includes feeders on such things as fungi, organic detritus, nematodes, and insect eggs and larvae (Krantz, 1978). Nasr et al,. (1990) described different immature stages of the species Proctolaelaps bickleyi, its biological aspects and feeding habits when feed on three soil fungi Rhizoctonia solani, Botrytis fabae and Aspergillus niger. They recorded that $R$. solani significantly accelerated the development compared with $B$. fabae and $A$. niger. Afifi (1980) found that Chiropturopoda sp. fed on larvae of Musca domestica oviposited 86 eggs/female, and only 13 eggs/female on mycelia of Penicillium viridus. Ahmed (1984) found that Urodiaspis sp. 1 fed on acarid mites oviposited 13 eggs / female, and Urodiaspis sp.2 fed on fungal mycelia produced 7 eggs /female. According to the previous studies data indicated that the uropodid mite In the cuurrent study it was noticed that $U$. krantzi not able to transmit Fusarium oxysporum and Rhizoctonia solani either through their faeces nor through their surface. So it was important to study it's ability to control these fungi. Also, in this study it was found that the uropodid mite $U$. krantzi laid few numbers of eggs when fed on $R$. solani, at the same time it was able to lay large number of eggs and live longer when fed on F. oxysporum. Therefore it was important to study the ability of $U$. krantzi to control tomato wilt disease which caused by Fusarium oxysporum. Finally, it can be concluded that prey species greatly affected the duration of the development, longevity and fecundity of uropodid mite, Uroobovilla krantzi. 
Table 1. Effect of different fungi on the duration of uropodid mite Uroobovilla krantzi at $25^{\circ} \mathrm{C}$ and $80 \%$ R.H.

\begin{tabular}{|c|c|c|c|}
\hline Biological aspect & Sex & Diet & Mean (days) \pm S.D. \\
\hline \multirow[t]{4}{*}{ Incubation period } & q & \multirow[t]{2}{*}{ F. oxysporum } & $\begin{array}{l}4.0 \pm 0.67 \\
(3.2-4.8)\end{array}$ \\
\hline & $\pi$ & & $\begin{array}{l}4.0 \pm 0.66 \\
(2.8-5.2)\end{array}$ \\
\hline & q & \multirow[t]{2}{*}{ R. solani } & $\begin{array}{l}4.7 \pm 0.67 \\
(4.3-5.7)\end{array}$ \\
\hline & $\sigma^{2}$ & & $\begin{array}{l}4.4 \pm 0.70 \\
(4.0-6.0)\end{array}$ \\
\hline \multirow[t]{4}{*}{ Life cycle } & q & \multirow[t]{2}{*}{ F. oxysporum } & $\begin{array}{c}35.1 \pm 2.28 \\
(31.5-39.5)\end{array}$ \\
\hline & 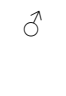 & & $\begin{array}{c}37.3 \pm 4.5 \\
(30.0-45.0)\end{array}$ \\
\hline & q & \multirow[t]{2}{*}{ R. solani } & $\begin{array}{c}34.6 \pm 2.11 \\
(31.9-38.1)\end{array}$ \\
\hline & $\sigma^{2}$ & & $\begin{array}{c}36.5 \pm 2.01 \\
(33.0-39.0)\end{array}$ \\
\hline \multirow[t]{4}{*}{ Longevity } & 우 & \multirow[t]{2}{*}{ F. oxysporum } & $\begin{array}{c}163.3 \pm 24.25 \\
(104.0-191.0)\end{array}$ \\
\hline & $\sigma^{2}$ & & $\begin{array}{l}198.4+53.29 \\
(73.0-253.0)\end{array}$ \\
\hline & 우 & \multirow[t]{2}{*}{ R. solani } & $\begin{array}{l}92.1 \pm 16.89 \\
(75.0-129.0)\end{array}$ \\
\hline & $\sigma^{2}$ & & $\begin{array}{c}72.1 \pm 9.76 \\
(60-93)\end{array}$ \\
\hline
\end{tabular}

Table 2. Effect of different fungi on the longevity (per days) and fecundity of uropodid mite Uroobovilla krantzi adult female at $25^{\circ} \mathrm{C}$ and $80 \%$ R.H.

\begin{tabular}{|c|c|c|}
\hline Biological aspect & Diet & Mean \pm S.D. \\
\hline Preoviposition period & F. oxysporum & $4.8 \pm 0.91$ \\
& & $(4-6)$ \\
\cline { 2 - 3 } & R. solani & $8.3 \pm 1.15$ \\
& & $(6.8-10.2)$ \\
\hline Oviposition period & F. oxysporum & $129.6 \pm 22.34$ \\
& & $(86.5-158.5)$ \\
\cline { 2 - 3 } & R. solani & $43.6 \pm 16.47$ \\
& & $(30.2-85.8)$ \\
\hline Postoviposition period & F. oxysporum & $22.5 \pm 5.62$ \\
& & $(13.6-27.4)$ \\
\cline { 2 - 3 } & R. solani & $28.6 \pm 3.41$ \\
& & $(25.0-36.0)$ \\
\hline Fecundity & F. oxysporum & $123.0 \pm 36.95$ \\
(No. of eggs) & R. solani & $(75.0-200.0)$ \\
& & $34.6 \pm 12.81$ \\
& & $(14.5-50.5)$ \\
\hline
\end{tabular}


Table 3. Effect of different fungi on the biological aspects of the uropodid mite Uroobovilla krantzi at $25^{\circ} \mathrm{C}$ and $80 \%$ R.H.

\begin{tabular}{|c|c|c|c|c|}
\hline Biological aspect & Source & F. & P. & L.S.D. at 0.05 level \\
\hline \multirow[t]{3}{*}{ Incubation period } & Sex & 0.491 & $0.488^{\mathrm{ns}}$ & \multirow[t]{2}{*}{0.4341} \\
\hline & Diet & 6.6 & $0.0145^{*}$ & \\
\hline & Int. Sex x Diet & 0.491 & $0.488^{\text {ns }}$ & \\
\hline \multirow[t]{3}{*}{ Life cycle } & Sex & 4.9136 & $0.0331^{*}$ & \multirow[t]{2}{*}{1.8756} \\
\hline & Diet & 0.494 & $0.4867^{\mathrm{ns}}$ & \\
\hline & Int. Sex x Diet & 0.026 & $0.8721^{\text {ns }}$ & \\
\hline \multirow[t]{3}{*}{ Longevity } & Sex & 0.5987 & $0.444^{\mathrm{ns}}$ & \multirow[t]{2}{*}{19.788} \\
\hline & Diet & 102.45 & $0.000^{* * *}$ & \\
\hline & Int. Sex x Diet & 7.9721 & $0.008^{* *}$ & \\
\hline Fecundity & Diet & 51.08 & $0.000^{* * *}$ & 12.54 \\
\hline
\end{tabular}

\section{REFERENCES}

1. Abbassy, M. A., S. A. Montasser, M. H. Abd Allah and M. H. Mowafi. 1991.The ability of two uropodid mites to feed and develop on free-living nematodes.AlAzher J. Agric. Res., 13: 237-246.

2. Afifi, A. M. 1980. Occurrence of mites in different organic manures. Ph. D. Thesis, Fac. Agric. Cairo Univ., 202 pp.

3. Ahmed, M. A. 1984. Biology of some soil fauna on some soil organisms.M.Sc. Thesis, Fac. Agric. Zagazig Univ.,

4. El-Bishlawy, S. M. and A. M. Afifi. 1982. Life history of fungivorous mite, Trichouropoda patavina (Canestrini) (Acari : Gamasida: Uropodidae). Proc. Egypt s National Conf./ Ent. Dec., 1: 15-24.

5. Hughes, T. E. 1959. Mites, or the Acari. The Athlone Press, London, 225 p.

6. Krantz, G. W. 1978. A Manual of Acarology. Oregon State Univ. Book Stores, Inc., Corvallis, Oregon, 335p.

7. Mowafi, N. H. 2005. Biological studies and feeding habits of the mite species Chiropturopoda bakeri Zaher and Afifi (Acarina : Uropodidae). Egyptian Journal of Biological Control,15 (2):97-98.

8. Nasr, A.K., M.S. Nawar and M.H. Mowafi. 1990. Biological studies on Proctolaelaps bickleyi Bram (Acari: Gamasida: Ascidae). Bull. Zool. Soc. Egypt, 39:89-100.

9. Nawar. M. S., G. M. Shereef and M. A. Ahmed. 1993. Effect of food on development, reproduction and survival of Chiropturopoda bakeri (Acarina :Uropodidae).Exp.\&Appl.Acarology,17:277-281. 
10. Radinovsky, S. 1965. The biology and ecology of granary mites of Pacific Northwest. III. Life history and development of Leiodinychus krameri (Acarina : Uropodidae). Ann, Ent. Soc. Amer.58: 259-267.

11. Radinovsky, S. and G.W. Krantz. 1961. The biology and ecology of granary mites of the Pacific Northwest. II. Techniques foe laboratory observations and rearing. Ann. Ent. Soc. Amer., 54: 512-518.

12. Willis, R. R. and R. C. Axtell. 1968. Mites predators of the house fly. A comparison of Fuscuropoda veetans and Macrocheles muscaedomesticae. J. Econ. Entomol., $61: 1669-1674$.

13. Zaher, M. A. 1986. Survey and ecological studies on phytophagous, predaceous and soil mites in Egypt. II- Predaceous and non-phytophagous mites (Nile valley and Delta). PL-480 Program. USA Project No. EG- ARS-30. Grant No. FG-EG-139, 567 pp 


\section{Uroobovilla krantzi (Zaher and Afifi) دراسات بيولوجية على الاكاروس} (ذات الثغر المتوسط : يوروبوديدى) عند تغذيته على نوعين من الفطريات

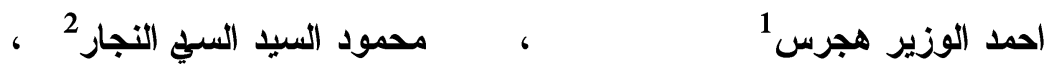

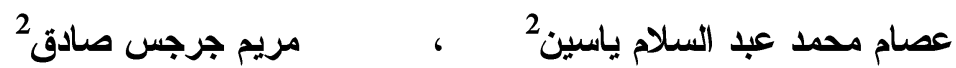

$$
\text { r r معهم علم الحبوان - كلية العلوم- جامعة المنصورة - المنصورة }
$$

أثبتت هذه الدر اسة و التي أجريت تحت ظروف المعمل أن نوع الغذاء المستخدم فى تغذية

لاكاروس Uroobovilla krantzi و المنتمى لعائلة Uropodidae اثر بصورة معنوية على فترة حضانة البيض Incubation period لهذا الاكاروس (ذكور و إناث) حينما تغذى على كل من Life cycle ألفطريين Rhizoctonia solani Fusarium oxysporium أما بالنسبة لدورة حياة الأفراد فلم تتأثز هذه الفترة حيت استغرقت هذه المدة زمنا مقداره 35.1 و 34.6 يوم على التو الي عند تغذية الإناث على كل من الفطريين السابقين على الترتيب بينما كانت هذه المدة 35.1 و 34.6 يوما للذكور على التو الي. وكان لنوع الغذاء المستخدم تأثيرا عالي المعنوية على عدد البيض الذي تضعه الأنثى حيث ذاد هذا العدد بصورة كبير جدا عند التغذية على الفطر F. oxysporium إلى أن وصل إلى 123.0 بيضة مقارنة ب 34.6 بيضة فقط عندما تغذت الأفراد الإناث على الفطر و أثبتت الدر اسة ايضا أن نوع الغذاء اثر بصورة كبيرة جدا على طول فترة الأفراد البالغة Longevity حيث استغرقت هذه المدة زمنا مقداره 163.3و 92.1 يوما للأفر اد الإناث عندما تغذت على كل من

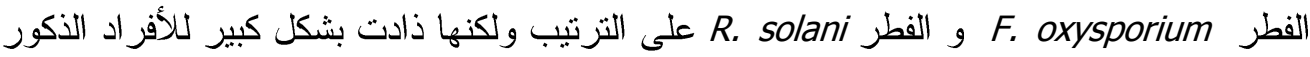

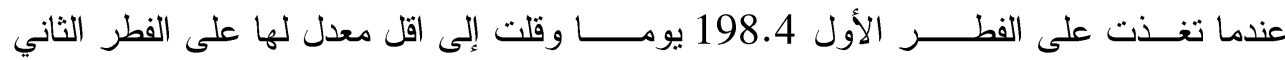
ووصلت إلى 72.1 يوما. 